\title{
A CONTRIBUTION TO THE MEDICINAL PLANTS OF SAHASTRADHARA, DISTRICT DEHRADUN, UTTARAKHAND (WITH ETHENOBOTANICAL NOTES)
}

\author{
Bisht AS*, Bhatt AB \\ Department of Botany, HNB Garhwal University Srinagar (Garhwal) Uttarakhand 246174, INDIA \\ *Corresponding Author's Email: adityabisht1234@yahoo.com
}

Received 20 July 2012; Review Completed 31 July 2012; Accepted 14 Aug 2012, Available online 15 Sep 2012

\begin{abstract}
:
The Himalaya with gushing rivers, alpine meadows, majestic snow claded peaks, enhancing lakes and a rich diverse flora and fauna is rightly described as the " abode of God'. Garhwal Himalaya provides enormous benefits to the human being in the form of shelter, food, water, medicine, fuel and industrial products and fodder. Further it has the potential for providing many more benefits still unknown. The plants protect topsoil, ensure the quality of the water and provide food etc, for all other living beings of the biosphere. Biological extinction has been a natural phenomenon in the geological past however man's interference has speeded extinction at a faster rate. Human beings are involved in destroying the vegetation at an alarming rate resulting in the loss of biodiversity of the biosphere. Himalayan resources are being depleted and converted in to ash each day through biotic pressure coupled with undisciplined exploitation, damage and destruction

Key words: Ethnobotany, Garhwal Himalaya, Ayurvedic, Unani medicine.
\end{abstract}

\section{INTRODUCTION:}

Himalaya represents one of the most important mega centres of the biodiversity, sharing over fifty percent of the vegetational wealth of the Indian subcontinent. In the recent past there has been a deep concern and awareness for the conservation of the fragile Himalayan ecosystem. The diversity, copiousness as well as uniqueness of the plant components in various habitats retained sound and have maintained the aesthetic environment and the serenity of the Himalaya. However in the recent past couple of years, excessive exploitation of vegetation, unplanned land use, natural disasters and several developmental processes accelerated deterioration of biodiversity and harmony of the Himalaya ecosystem.

Garhwal Himalaya possesses luxuriant and varied vegetation within the Himalaya region. Almost every plant has economic value from either a nutritional, aesthetic or medicinal viewpoint. In fact, a large percentage of crude drugs in the Indian market come from this Himalayan area ${ }^{1}$. According to cumulative evidence, the Garhwal Himalaya has more than 3500 species of flowering plants, most of which are in forest and alpine meadows ${ }^{2}$. In India out of an estimated 15000-16000 flowering plant species, about 1500 (10\%) have already come under the various categories of threatened plants ${ }^{3}$. The same number of species is used in Indian traditional system of medicine, that is, 600 species with more than 8000 herbal remedies in Ayurvedic, 500 specie in Unani, and 550 species in phytopharmaceutical industries. Nearly thirty species from the Garhwal Himalaya have been listed in various categories under threat in the India Red Data Books ${ }^{4 \& 5}$ of which 24 species are from high altitude alpine regions. Recently ${ }^{2}$ listed 45 more species (excluding Red data Books) which need special attention for conservation, of these Acorus calamus Cinnamomum spp, Hedychium spicatum Zanthoxylum alatum, Paris polyphylla, Valeriana spp, Polygonatum spp., Roscoea spp and Malaxis muscifera, are already facing severe pressure.
Himalaya is rich repository of important medicinal and aromatic plants. The efficacy of medicinal plants growth here is perhaps as old as these hills ${ }^{6}$. Several workers took interest in this region for the collection and preservation of medicinal and aromatic plants in past even before $19^{\text {th }}$ century ${ }^{7}$. Alpine and sub alpine area of Uttarakhand Himalaya is the largest nursery of the medicinal plants among all the Himalayan hill state and provides matchless wealth of highly prized medicinal and aromatic plants. The ethnobotanical account of Garhwal Himalaya ${ }^{8}$ reveals that majority of traders collect wild medicinal plants from alpine and sub alpine zone especially before the onset of seed setting through untrained and unskilled labours from higher altitude and export them. This has led to the unscientific extraction of entire plants. In addition, the over exploitation changed the environmental conditions and original habitats that have led to gradual loss of plants. In many of the species the exploitation pressure has gone to the extent that these are at the verge of extinction and therefore has been declared as threatened, rare, vulnerable, or endangered depending on the frequency in the nature?

\section{STUDY AREA}

\section{Survey and Selection of Research Area}

After undertaking a survey of various zones in district Dehradun, the Sahastradhara area was finally selected for the present investigations. The Dehradun district lies between Lat. $29^{\circ} 55^{\prime \prime} 37^{\prime}-31^{\circ} 27^{\prime \prime} 3^{\prime} \mathrm{N}$ and Long $78^{\circ} 54^{\prime \prime} 3^{\prime}$ $80^{\circ} 2^{\prime \prime} 3^{\prime} 10^{\prime} \mathrm{E}$.

\section{Climate}

Climate of Garhwal Himalaya is strongly influenced by Indian monsoon. Generally the climate depends upon elevation, direction, latitude, precipitation and temperature. Humidity, solar radiation and wind speed are the important variables interacting with each other and determine the microclimate of a particular zone. 
Bisht et al

Journal of Drug Delivery \& Therapeutics; 2012, 2(5), 114-120

The climate of the area is determined by less severe summer months, higher precipitation and colder or more prolonged winters. The major output of precipitation is in the form of rainfall. The rainfall pattern in study area is monsoon dependent. The Southeast monsoon commences towards the end of June and it rains until mid of September. Northeast monsoon causes occasional winter showering during December to February. During summer months (April-July) the study area experiences moderately hot climate while December to February months the area features the coldest climate.

Humidity represents the amount of water vapour in the air. Absolute humidity is the actual amount of water in the air expressed as weight of water per unit of air. There is generally a daily rhythm in humidity in nature i.e. high at night and low during the day, etc. Relative humidity is normally highest during rainy season (June-Sep.) and it gradually decreases to winter seasons (Nov.-Feb.).

\section{METHODOLOGY}

The present investigation was a result of extensive and intensive field surveys, conducted during November 2009 to April 2011. The specimens were collected by usual methods of collection, preservation and maintenance of specimen in the herbarium ${ }^{10}$ with field notes viz. local names, habit, habitat, altitude range, color of flower, flowering and fruiting time, general availability, local use, etc.

The collected specimens were identified with the help of recent and relevant floras i.e Gaur ${ }^{11}$, Naithani ${ }^{12}$. Information on medicinal properties and qualities of various plant species have been gathered through personnel interview with the local inhabitants. Usually the information collected from the local vaidyas or medicinal practitioners however; occasionally the information was also recovered by housewives, rural old folk, and grazers of long experience.

\section{RESULT}

Species Richness and Contribution of families, genera and species

The present study comprises total 58 species respectively 30 families, 54species were dicotyledons (26 families) and 4 species of monocotyledons (4 families) collected during the study period. Out of the 30 angiospermic families, Detail statistics is presented in Table 1and 2.

\section{Eco-Taxonomic Feature}

The families were arranged according to Cronquist system of classification (1981). The genera and species were arranged alphabetically. Medico-ethnobotanical uses have also appended wherever applicable those plants are medicinal used.

\section{RANUNCULACEAE}

Rannunculus trichophyllus Hook.

Vern.Simariya, Piryali. Eng. Water fennel. Perennial erect or decumbent Herb, root stock fibrous short stem $15-25$ $\mathrm{cm}$ long, addressed hairy. With immersed leaves, multifid with capillary division. Flowers $1-1.5 \mathrm{~cm}$ across, solitary several yellows during June - Aug., waysides. Plant paste used in intermittent fever rheumatism and asthma.

\section{Thalictrum foliolosum DC.}

Vern. Mamiri. Erect branch herb, to $1-1.5 \mathrm{~m}$ high, leaves broadly orbicular or ovate oblong, obtusely crenate toothed. Flowers polygamous white or dull greenish purple. Flowering June - Aug. Root used in ophthalmia and also in colic and fever.

\section{PAPAVERACEAE}

\section{Argemone mexicana Linn.}

Vern. Kanjilu. Annual, Prickly herb, $20-100 \mathrm{~cm}$ tall, with yellow latex, lower leaves petiole, in rosette, upper ones sessile, elliptic - ovate, base cordate or semi amplexicaule. Flowers whitish color. sessile or shortly stalked, subtended by leaf like bract at the base. Fl. Apr. Jun \& Fr. July - Oct. commonly in waste place. Yellow latex for skin diseases and The seed emetic and narcotic used as medicine; root decoction as wormicide; root chewed in leucorrhoea.

\section{CANNABINACEAE}

Cannabis sativa Linn.

Vern. Bhang, Bhangula. Annual - Perennial erect aromatic herb or under shrubs, to $2.5 \mathrm{~m}$ high; bark fibrous. Leaves palmately 3-7 foliate or partite. Fl. and Fr. May - Oct. commonly found in roadside and wastes places. Bark fiber used for making ropes, sacs and rough clothes; stem as a fuel. Seed are used as condiment; seed - oil edible, besides, its leaves and flowers used as an intoxicating agent.

\section{URTICACEAE}

Urtica dioica Linn.

Vern. Kandali, Eng. Stinging Nettle. Perennial, erect, robust herbs or shrubs, $0.5-3 \mathrm{~m}$ high, stem branched from the base, bark fibrous, stem, branches, petioles and leaves covered with sharp, irritating, stinging hair. Flowers small, pale green, on long and tassel-like dropping or spreading $2-10 \mathrm{~cm}$ long paniculate cymes. Fl. and Fr.: Aug.-Apr. Common in waste places. Stem yild strong - shining fiber, used for sacs, ropes and mass; young branches and leaves used as delicious pot herb; seed oil edible as well as medicine in sciatica, rheumatism and several skin ailments; hair - wash leaf extract believed to avoid baldness.

\section{CHENOPODACEAE}

Chenopodium album Linn.

Vern. Bathua. Annual glabrous, simple or branched herbs $20-120 \mathrm{~cm}$. high stem often red brown clothed with white powdery mass. Fl \& Fr.: June - Nov. Leaves used as potvegetable; breads prepared from the grinned grains. 
Bisht et al Journal of Drug Delivery \& Therapeutics; 2012, 2(5), 114-120

Table 1: Brief statistical synopsis of number and percentage of families, genera and species of Angiosperms,

Dicotyledons and Monocotyledones

\begin{tabular}{|l|l|l|l|l|l|l|}
\hline Groups & Families & Genera & \multicolumn{3}{l|}{ Species } \\
\hline & Number & Percent & Number & Percent & Number & Percent \\
\hline Dicotyledones & 26 & 86.67 & 51 & 92.72 & 54 & 93.10 \\
\hline Monocotyledons & 4 & 13.34 & 4 & 7.27 & 4 & 6.89 \\
\hline Total & 30 & 100 & 55 & 100 & 58 & 100 \\
\hline
\end{tabular}

Table 2: Contribution of family, genera and species in study area

\begin{tabular}{|c|c|c|c|c|c|}
\hline S. No. & Family & Genera & & Species & \\
\hline & & Number & Percent & Number & Percent \\
\hline 1 & Ranunculaceae & 2 & 3.63 & 2 & 3.44 \\
\hline 2 & Papaveraceae & 1 & 1.81 & 1 & 1.72 \\
\hline 3 & Urticaceae & 1 & 1.81 & 1 & 1.72 \\
\hline 4 & Chenopodiaceae & 1 & 1.81 & 1 & 1.72 \\
\hline 5 & Amaranthaceae & 5 & 9.09 & 6 & 10.34 \\
\hline 6 & Polygonaceae & 2 & 3.63 & 3 & 5.17 \\
\hline 7 & Tiliaceae & 1 & 1.81 & 1 & 1.72 \\
\hline 8 & Malvaceae & 2 & 3.63 & 2 & 3.44 \\
\hline 9 & Violaceae & 2 & 3.63 & 2 & 3.44 \\
\hline 10 & Cucurbitaceae & 2 & 3.63 & 2 & 3.44 \\
\hline 11 & Begoniaceae & 2 & 3.63 & 2 & 3.44 \\
\hline 12 & Rosaceae & 2 & 3.63 & 2 & 3.44 \\
\hline 13 & Mimosaceae & 1 & 1.81 & 1 & 1.72 \\
\hline 14 & Ceasalpiniaceae & 2 & 3.63 & 2 & 3.44 \\
\hline 15 & Euphorbiaceae & 6 & 10.90 & 6 & 10.34 \\
\hline 16 & Vitaceae & 1 & 1.81 & 1 & 1.72 \\
\hline 17 & Linaceae & 1 & 1.81 & 1 & 1.72 \\
\hline 18 & Oxalidaceae & 1 & 1.81 & 1 & 1.72 \\
\hline 19 & Geraniaceae & 1 & 1.81 & 1 & 1.72 \\
\hline 20 & Balsaminaceae & 1 & 1.81 & 1 & 1.72 \\
\hline 21 & Apiaceae & 1 & 1.81 & 1 & 1.72 \\
\hline 22 & Gentianaceae & 1 & 1.81 & 1 & 1.72 \\
\hline 23 & Solanaceae & 2 & 3.63 & 2 & 3.44 \\
\hline 24 & Acanthaceae & 2 & 3.63 & 2 & 3.44 \\
\hline 25 & Lamiaceae & 2 & 3.63 & 2 & 3.44 \\
\hline 26 & Asteraceae & 7 & 12.72 & 8 & 13.79 \\
\hline 27 & Cyperaceae & 1 & 1.81 & 1 & 1.72 \\
\hline 28 & Poaceae & 1 & 1.81 & 1 & 1.72 \\
\hline 29 & Liliaceae & 1 & 1.81 & 1 & 1.72 \\
\hline \multirow[t]{2}{*}{30} & Dioscoraceae & 1 & 1.81 & 1 & 1.72 \\
\hline & Total & 55 & 100 & 58 & 100 \\
\hline
\end{tabular}

\section{AMARANTHACEAE}

Aerua lentan. Juss.

Vern. Gorkhabundi fam : Anaran thaceal Erect, branched herbs; leave alternte, acute and entire; flowers greenish white yorming globose clusters. Plant is diusetic used in lithiasis and roots used in headache treatment.

\section{Achyranthes aspera Blume}

Vern. Chicheree, Latjira. Annual-perennial slender herbs or under shrubs stem woody at base, patently hairy. Leaves opposite, narrowly ovate-lanceolate, acuminate, thin, dull green above, sparsely pubescent on both surfaces. Fl. and Fr.: Aug.-Dec. Common, on shady and moist places, Root infusion taken in malarial fever. Leaf extract supposed to facilitate delivery, root powder used in making local beverage, plant decoction used in dropsy and bronchitis. Ameranthus spinosa L.

Vern. Jaungali Chaulai. Erect glabrous herb, hard radish stem many groved branches with divert cat spines, leaves ovate and lanceolate, Used to care eczeni colic and gonorrhoea.

Areva lantana Juss.

Vern. Gorkha bhindi, Erect, branched herbs leaves alternate acute and entire flowers greenish white, forming 
globose clusters, Plant is diureatic used in litchiasis and roots used in headache treatment

Areva javanica Juss.

Annual herb, erect branched stem, leaves alternate oblong spathulate densely tomantos flowers in terminal. Decoction of plants useful in removing swelling.

Aletrnanthera sessilis (Linn.) R.Br.

A prostrate herb, flowers in small, axillary sessile, long head, spike in florescence, flowers white, shiny. Used as galactagogue, given in both for phlyctena of young children.

\section{Celosia argentea Linn.}

Vern. Sarwari. Annual herb, grooved braches, leafs linear rarely ovate, acute, entire. Flowers at first pinkish then turn white with terminal spike. Seeds are efficacious remedy Diorrhoea.

\section{POLYGONACEAE}

Polygonum recumbens. Royle

Prostate branching herbs; leaves broadly ovate; stipules with 2- long bristles; flowers white or pink. Fl. \& Fr. Aug. - Sept. $2200 \mathrm{~m}$

\section{Rumex vesicarius Linn.}

Vern. Ambari. Annual, monoecious, branched herb. Leaves acute or obtuse, elliptic, petiole as long as blade, fruits white or pink. The herb used in heart trouble, constipation and disease of spleen. Leaves as an antidote to snake venom, while seeds as an antidote to scorpion venom.

\section{Rumex nepalensis Spreng.}

Vern. Almora. Pahari Palak. Perennial, robust, glabrous herbs with thick rootstock and hollow ribbed stem, 50 $150 \mathrm{~cm}$ high flower pale green. Fl; April - Aug and Fr; Aug - Oct. The sap of leaves and stem is applied on cuts for its astringent powder.

\section{TILIACEAE}

\section{Corchorus capsularis Linn.}

Vern. Narcha. Annual, Branched glabrous stem: leaves acute with serrate margin. Flowering stage occur in November. Decoction of root and unripe fruit given in Diarrhoea used as an antiperiodic anthelmintic and intestinal antiseptic also.

\section{MALVACEAE}

\section{Sida acuta}

Vern. Kareta. Perennial shrubby, much branched hairy stem, leafs long, lanceolate, serrate, shorter then stipule, yellow flowers. Roots in fusion with ginger in intermittent fever and cure for rheumatism.

\section{Abutilon indicum}

Vern. Pilli buti. A wild shrub, branched tape root, erract, solid branched stem, alternate, simple, petiolate leaf. Axillary in florescence with yellow flowers. In fusion of roots in fever, decoction of leaves as an emollient.
VIOLACEAE

Viola biflora J. Smith in Rees.

Vern. Banfsa. Perennial, glabrous, acaulescent herbs, with stout slender roots. Basal leaves in rosette. Flowers lilac or purplish white. Fl.: Mar.-Jun. and Fr.:- Jul.-Sep. Common in moist shady places, altitude $800 \mathrm{~m}$. The whole plant either in the form of extract or powder taken as diaphoretic, useful in skin and blood diseases, flowers and leaves boiled with tea, supposed to be good for fever and cough.

\section{CUCURBITACEAE}

\section{Trichosanthes palmate}

Vern. Indrayan. Annual, weak stemmed, climbing by means of tendrils, much branced roots, alternate leaf divided palmately, dioecious flowers, male flowers in large number and companulate. Fruit is smoked as a remedy for asthma and fruits and root boiled with mustard oil are used for headache.

Coccinia grandis (Linn.) Voigt.

Ver. Kaduri, Eng. Ivoy Gourd. Perennial, climbing herbs with tuberous roots, tendrils simple. Leaves an ovate, cordate, segment denticulate. Flowers white, fruits ellipsoid, with rounded, rarely acute ends, green with white strips, orange red on ripening. Fl.: Jan.-Jul. and Fr.: Aug.Oct., altitude $1800 \mathrm{~m}$. Leaves and root juice given in diabetes, leaves also supposed to be antiseptic; fruit juice given in gonorrhea.

\section{BEGONIACEAE}

Begonia venusta

Annual climber with the help of tip tendril, flowers brightly coloured and showy. Leafs and flowers are used as antidote of snake bite.

\section{Tecoma stens Juss.}

Vern. Yellow bell (Eng.). annual tree, solid, erract, branched stem, pinnate leafs and large scarlet or orange flowers. Roots as an antidote of snake bite and scorpion sting.

\section{ROSACEAE}

Pyracantha crenulata (D.Don) M. Roemer.

Vern. Ghingaru. Evergreen, spinescent, undershrubs or shrubs, 5m high, spines straight, stout, bark ashy grey. Leaves crowded at the ends of short lateral branches, shining green above, glaucous beneath, and flowers white. Fl.: Mar.-May and Fr.: Jun.-Oct Branches used for walking sticks and tool handles, fruits rarely edible, flowers useful in apiculture as bee forage and plant act as soil binder.

Pyrus pashia Buch.-Ham. ex D.Don.

Vern. Malu or Mahel. Deciduous tree, to $15 \mathrm{~cm}$ in high; Flowers large, white tinged - brownish, Feb - March. Leaves and twig as fodder. Ripe fruits edible and also used in digestive disorders; wood made in to stick; flower use fuel in apiculture; believed to check soil erosion in landslide zones.

\section{MIMOSACEAE}

Mimosa pudica 
Vern. Lajwanti. Annual prickly under shrub, branched prickly stem, compound leaf which is sensitive to touch, a globose, axillary head, pink flowers. Decoction of roots in leprosy, leafs as tonic.

\section{CAESALPINIACEAE}

\section{Cassia fistula}

Vern. Amaltas. An annual herb or medium sized tree, compound, alternate, peripinnate leafs, racemose in florescence having pedicellate yellow flower. Pulp called cassia pulp (from fruits) as a laxative admixture with senna.

\section{Bauhinia veriegata Linn.}

Vern. Kachnar. Medium sized decioduous tree, bark dark brown, leaves deeply cordte, flowers with or pinkish in racemose. Dried flowers for diarrhea, bark is astringent and used as tonic in fever.

\section{EUPHORBIACEAE}

Euphorbia hypericifolia Linn.

Vern. Dudhi Fam; Euphorbicicel Annual herb, erect with obouate obtuse leaues; flowers axillry branched, cymose.

Infusion of dried leaves is romedy in dysentery, dirrtoe and also given to child with milk as a tonic.

\section{Euphobia microphyalla}

Vern. Dudhi. Annual herb, numerous stem, spreading from the roots, leaves opposite rounded and sub trumcate at apex with pink margin This Plant is given along with the cryptoletis spp. To nursing mother in milk deficient.

\section{Euphobia hirta Linn.}

Vern. Doda The herbaceous erect solid hairy and branched or little branched, cyathium inflorescence. Naked male and female flower lack perianth. Decoction is used in asthma and chronic bronchial affections.

\section{Phyllanthus amarus Schum \& Thonn.}

Vern. Bumianwala. Annual erect, glabrous, shallow rooted herbs, $30-60 \mathrm{~cm}$ in high; branches soubrette or 3 gonous, spreading. Leaves simple appears or rounded ends glabrous often overlapping; stipules subulate. Flower yellowish. Fl \& Fr. Jun - Nov. commonly occurs in waste places. Herb as an astringent stomachache diuretic and febrifuge; leaves said to bear antibacterial properties.

\section{Riccirus conmunis.}

Vern. Arind, arand. Tall annual or perennial shrub; erect, solid branched stem; terminal panicled cyme inflorescence; unisexual monoecious flower. Castoroil is used $s$ a tonic to pregnant women and also useful in urinary disorders

\section{Emblica officinalis Linn.}

Vern. Amla. Annual tree, solid, erect, branched. Leafs opposite. Fruits are rich in vitamin $C$ and useful as an liver tonic.

\section{LINACEAE}

Reinwardtia indica Dumortier
Vern. Phiunli. Perennial, erect or sub-erect, tufted, glabrous under shrubs or herbs, with woody base. Stem branched from the base, terete or angular, leaves ellipticobovate, acute or rounded at apex and flowers yellow. Fl. and Fr.: Feb.-Jun. Common in moist localities, Petals chewed as tongue wash, considered sacred, as indicator of pollutants.

\section{OXALIDACEAE}

\section{Oxalis corniculata Linn.}

Vern. Bhilmori, Khati-Buti, Eng. Indian Sorrel. Perennial or annual prostates suberect herbs. Rooting at nodes, stem pubescent, creeping. Leaves 3-foliate. Flowers 2-3 in subumbels and yellow with dark purplish streaks. Flowering and fruiting almost throughout the year. Common in all study sites, at $800 \mathrm{~m}$. Leaves taken as salad or cooked as vegetable and leaf juice dropped in cataract and conjunctivitis.

\section{GERANIACEAE}

Geranium wallichianum D.Don ex Sweet.

Vern. Ratanjot, Kaphlya, Eng. Robert Geranium. Perennial, erect or trailing, pubescent herbs, to $80 \mathrm{~cm}$ long, rootstock thick, woody. Leaves orbicular, palmately 3-5 lobed segments deeply or irregularly toothed, tip acute, pubescent on both surfaces. Flowers light purple, Fl.: Jul.Sep. Root juice in diarrhea and ophthalmic, red dye obtained from the roots said to promote growth of hairs, as well as dye to woolen clothes.

\section{BALSAMINACEAE}

Impatiens thomsonii Hook.

Vern. Gulmehandi. Annuals herbs, flowers light yellow Fl \& Fr. Jul - Oct. Common: shady as well as exposed localities road sides, waste land 500m. Seed edible powder of roasted seed with honey given to relieve cough and cold.

\section{APIACEAE (UMBELLIFERAE)}

Apium gravelens Linn.

Vern. Ajmud. Biennial shrub erect, branched stem radical leaves pinnate deeply segmented. Root used as diuretic and given as stimulant and liver and spleen disorder.

\section{GENTIANACEAE}

Gentiana aprica Decne.

Vern. Chirotu. Annual, erect herbs, $2.5-10 \mathrm{~cm}$ high, with simple or little branched, purplish stem. Leaves opposite, basal leaves in rosettes, flower 2-sexual, blue-lilac, in terminal, stalked racemes. Fl.: Jan.-May and Fr.: Apr.-Jun. Plant juice with flower decoction of Viola sp. is given in tea as a remedy of intermittent fever and headache.

\section{SOLANACEAE}

\section{Solanum nigrum Linn.}

Vern. Mako, An annual herb erect branched, cylindrical stem, simple alternate acute leaves flowers pedicilate white and cymose type. Roots, leaves and fruits after heating applied on wounds and burns, extract chiefly used in urinary troubles and skin diseases.

Physalis minima. Linn. 
Vern. Chirpoti. Annual herbaceous, erect stem, leaves ovate acute, flower solitary, yellow in color. Fruits is considered as tonic diuretic and purgative.

\section{LAMIACEAE (LABIATAE)}

Nepeta laevigata Wallich ex Benth. in Wallich.

Vern. Nueet, Eng. Catmint. Tall, erect, branched herbs, 30$90 \mathrm{~cm}$ high. Leaves ovate-cordate. Flower lilac, Fl. and Fr.: Jul.-Nov. Decoction of leaves and seeds taken in fever. Leaves also yield essential oil.

\section{Ocimum basilicum}

Vern. Bantulsi, Eng. Common Marjoram. Perennial, aromatic, hairy herbs. Leaves ovate rarely toothed, pubescent on both surfaces. Flower pink or purplish. Fl.: May-Aug. and Fr.: Sep.-Oct. Plant extract used in bronchitis, colic and diarrhea, leaves eaten as vegetable and flavoring agent, flowering branches hung on the houses to get rid of bad sprits.

\section{ACANTHACEAE}

\section{Peristrophae Bnalvis Nees.}

Vern. Pitpapra. Herbaceous, stem and branches; leaves ovate, densely linceiolate; flower in trichotomous cyme. Infusion of rice is good antidot for snake poison

Adothoda vasica Ness.

Vern. Basingu. An annual herb woody below and herbaceous above branched solid green stem opposite extipulate green herbaceous, leaves terminal spike inflorescence with sessile bisexual flower. Roots and leaves are used in asthma cough and bronchitis.

\section{ASTERACEAE (COMPOSITAE)}

Ageratum conyzoides Linn.

Vern. Gundrya, Eng. Goat weed. Annual, erect herbs, 40 $\mathrm{cm}$ high, stem hairy on nodes and young parts. Leaves ovate to sub-rhomboid, sparsely pubescent above, glandular-panculate beneath. Flowers small, white or purple-blue. Fl. and Fr.: Jan.-Dec. Plants with the root of Thallictrum foliosum made into paste and applied on sores, cuts and various skin ailments.

Anaphalis triplinervis (Sims) C.B. Clarke in Comp. Indicae

Vern. Buglya. Erect, rhizomatous herbs, $70 \mathrm{~cm}$ high. Leaves sessile, variable, ovate-lanceolate and acute with black point at apex, hairy above, white densely-tomontose beneath. Head (flower) discoid, shining white and brownish at base. Common in open places of oak forests, Leaf juice dropped in laceration of toes during rainy season. Paste of heads and leaves applied on cuts, wounds and boils. Fiber of leaves and stem used to lit the fire by friction of stones.

\section{Artemisia capillaris Thunb.}

Vern. Jhirun, Eng. Wormwood. Annual, glabrous or sparsely, hairy herbs to $70 \mathrm{~cm}$ high. Stem purplish-brown, grooved with woody rootstock. Leaves 1-3 pinnatisect, flowers small and green in color. Fl. and Fr.: Jul.-Nov. Decoction of leaves taken as a bitter tonic for worms and colic, twigs used as brooms.

\section{Artemisia roxburghiana Wallich ex Besser}

Vern. Kunjaa, Eng. Indian Wormwood. Perennial, pubescent, undershrubs, 1-2m high. Stem ribbed or paleyellow, leaves 2-pinnatifid, rachis and leaf surface pubescent. Heads sessile or shortly pedunculate and greenish-white. Fl. and Fr.: Sep.-Nov. Plant extract antipyretic, tonic and also rubbed on skin allergy.

Bidens pilosa Linn.

Vern. Kumra, Eng. Bur-Marigold. Annual, glabrous or sparsely hairy erect herb $120 \mathrm{~cm}$ high. Stem purplishgreen, tetra-gonous and striate, leaves opposite, pinnately, 3-5 lobed and toothed. Heads radiate and white-yellow. Fl. and Fr.: Mar.-Aug. Plant extract with honey used in cough and bronchitis, the vegetable of the herbs considered useful in leucoderma and plants browsed as fodder.

Emilia sonchifolia (Linn.) DC. in Wight.

Vern. Hirankuri, Dudhi. Annual, diffused or erectascending, weak herbs to $30 \mathrm{~cm}$ high. Stem pale-brown, much branched and glabrous. Leaves variable, coarsely toothed, heads purple and discoid. Fl. and Fr.: Feb.-Jun.. Occasionally upper leaves cooked as vegetable. Herbs used as febrifuge and leaf juice used in eye inflammation and night blindness.

Sonchus asper (Linn.) Hill.

Vern. Pili-dudhi, Choplya, Eng. Rough Sow Thistle. Annual, glabrous or sparsely-hairy herbs, $15-80 \mathrm{~cm}$ high. Leaves hard, lanceolate, spinous-toothed and unequal, heads yellow. Fl. and Fr.: Mar.-Sep. The plant used as a tonic to purify blood and in hepatitis and leaf paste applied on wounds.

\section{MONOCOTYLEDON \\ CYPERACEAE}

Cyperus rotundus Retz.

Vern. Murya-ghas. Annual herb with tufted rhizome and creeping with fibrous root.leaves basal, narrowly linear and half of the stem. Spikelets white and much compressed. Fl. and Fr.: Apr.-Nov. Inflorescence used in curing dysentery.

\section{POACEAE(GRAMINEAE)}

Cynodon dactylon (Linn.) Persoon.

Vern. Dubla, Eng. Dhoob Grass. Perennial, rhizomatous grass, culms prostate or ascending from the creeping base. Leaves linear-subulate, glaucous, sheath glabrous. Spikes digitate and green or purplish. Fl. and Fr.: Jan.-Dec. Common in waste places, at $1800 \mathrm{~m}$. Root juice taken in fever and in internal injury. Plant is believed pious and used in several religious ceremonies.

\section{LILIACEAE}

\section{Asparagus racemosus Willd.}

Vern. Satavari, Jhirni. Tall much branched, scandent or somewhat climbing shrubs, with tuberous rootstock and white flowers in April and Fruiting in Nov. Root aphrodisiac, antiseptic, refrigerant often used with fresh water or milk. Root decoction with jaggery used an abortifacient. 
Bisht et al

DIOSCORACEAE

Journal of Drug Delivery \& Therapeutics; 2012, 2(5), 114-120

Dioscorea bulbifera Linn.

Vern. Genthi . Eng. Potato Yam. Annual - Perennial, glabrous, slender, twining herbs; tuber solitary, globose or ovoid; stem angular or ribbed, bearing numerous, axillary, grey brown, warted bulbils. Commonly found in waste places.. Flower unisexual small, pale green in colour. Fl: July - Nov. and Fr.; Sept - Jan. Tuber arte cooked as vegetable. Dried tuber used as an antiseptic, applied on burns and wounds, flowers occasionally visited by bee.

\section{DISCUSSION}

Knowledge of flora and vegetation of any area is essential for the study of biodiversity, environment and conservation of natural resources ${ }^{14}$. The study area is rich in biodiversity corresponding to the climate and topography of the area, vegetation ranging from 500-900 $\mathrm{m}$ altitude, respectively. Different factors have influenced (lower or exceeded) the normal limit of vegetation type and flowering seasons. Natural vegetation in vicinity of towns and villages in the sub tropical belt has been subjected to more biotic disturbances as compared to the villages at high elevations. There is abundance of grasses and annuals during monsoon, whereas perennials, shrubs and trees mostly bloom during spring and summer.

The most attractive part of vegetation in the study area was the presence of numerous medicinal plant species, the fact is generally ignored by scientists. Each plant species has its own value in the form of fodder, fruits and vegetable, flowers as a bee forage, fibre, resin, tannin, gum, dye, ornamentation, psychomedicine and medicines, etc. These plant species are used against dropsy, bronchitis, boils and wounds, insect and snake bite, relieve from suffering of nettle sting, malarial fever, facilitate delivery, body pain, rheumatism, fever, cold and cough, gonorrhoea, colic and dyspepsia, diarrhea, digestive and respiratory disorders, diabetes and urinary ailments, relieving earache, body swelling and contusions, psychomedicines,

\section{REFERENCES}

1. Badoni, AK, Remarks on the high altitude medicinal plants of Garhwal Himalayas. Jour. Himalayan Studies and Regional Development. 1989-90. 13 \&14: 37-45.

2. Rawat, DS, Bhandari, BS. and Gaur R.D. Vegetational wealth. In: (eds. O.P. Kandari and O.P. Gusain) Garhwal Himalaya Nature, Culture and Society Pub.Co., Trans media House Srinagar (Garhwal). 2001, Pp 70-92

3. Rao, RR. Biodiversity in India (Floristic aspects) I 1994, Bishen Singh Mahendra Pal Singh, Dehra Dun.

4. Rao, R. R.. Biodiversity in India (Floristic aspects) II 1994, Bishen Singh Mahendra Pal Singh, Dehra Dun.

6. Nautiyal, M.C. Cultivation of medicinal plants and Biosphere reserve management in alpine zone. Conservation and management of Biological resources in Himalya. (Ed R.S Ramakrishan, 1996,

7. Burkill, I.H.. Chapters on the History of Botany in India. BSI, Howrah. 1965. treatments of migraines, hepatitis and headache, dysentery, etc. by villagers and Vaidhyas. Achyranthus aspera, Adathosa vasica, Agrimone maxicana, Anaphalis triplineris, Artemetia spp., Asparagus recemosus, Bidens pilosa, Begonia picta, Cassia fistula, Euphorbia hypericifolia, Geranium sp. Oxalis corniculata, Ocimum $s p$., etc. were the medicinally important species present in the study area.

The study has incorporated large number of plants fulfilling various economic values based on timbers, fibers, dyes, tannins, resin, medicine etc. Some of the rare and highly valuable drug yielding plants of the study area, include Artiemisia capillaries and - roots is stimulant, expectorant and yield aromatic oil and used in abdominal problem; Thalictrum foliolosum root and stem bark are ophthalmic, used in ulcer and dyes; Bergenia stracheyi roots used in kidney stone and genital disorders; Euphorbia Species tuberous roots used in tonic febrifuge and in stomach disorder; Dioscorea species- tubers are source of alkaloid; Oxalis corniculata - rhizome, carminative; Areva lantana species whole plant, antipyretic, febrifuge, tonic; Valeriana Spp. (Summaya) whole plant, febrifuge and tonic. The extinction of these medicinal plants from their natural habitat (particularly in this area) is a matter of great concern but it has not attracted the attention of naturalists and environmentalists $^{12}$. This is probably because the medicinal wealth of this area is little known hence no agency or related departments care for the protection and management of these continuously declining species of drug importance. Changing atmospheric conditions and lack of knowledge, infectious nature of some weeds are among the other factors responsible for the extinction of these important medicinal plant species.

ACKNOWLEDGEMENT: Authors are acknowledged to GBPIHED Almora, Uttarakhand for financial support .

8. Atkinson, E.T. 1882. The Himalayan Gazetteer Vol. 2 (reprint 1973) Cosmo Pub. Delhi.

9. Joshi, D.N. and Rawat, G.S. Need for conservation and propagation of alpine and sub alpine medicinal plants of northwest Himalaya. 1997, Ind. For. 123 (9): 8111-814.

10. Gaur, R.D.. Flora of the District Garhwal North West Himalaya (with ethnobotanical notes). 1999, Transmedia, Srinagar Garhwal, Uttaranchal. India.

11. Naithani, B.D.. Flora of Chamoli. 1985, 2 Vols, BSI Calcutta.

12. Bisht, A.S. Ecological studies of some important medicinal herbs; their multiplication and conservation in Garhwal Himalaya, India, 2005. Ph.D thesis submitted in Garhwal University Srinagar (Garhwal) Uttarakhand 